\title{
Diastereoselective Synthesis of Pyrrolidines and Prolines
}

Metal-Catalyzed

Asymmetric

Synthesis and

Stereoselective

Reactions

Key words

multicomponent

reaction

pyrrolidines

tetrahydrofuran<smiles>C1=CO[C@H](c2ccccc2)C1</smiles><smiles>CCOC(=[N+]=[N-])OCC</smiles><smiles>[M]CC=CC</smiles>

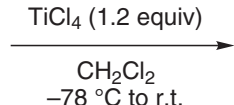

$1(88 \%$ ee)

2

$\mathrm{M}=\mathrm{SiMe}_{3}, \mathrm{SnBu}_{3}$<smiles>C=CCC1OC(c2ccccc2)CC1C(N)C(=O)OC</smiles>

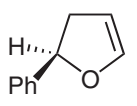

1
${\stackrel{\mathrm{NTS}}{\mathrm{CO}_{2} \mathrm{Et}}}^{+}$

2<smiles>[R]C([B])=C([10BH2])O[Na]</smiles>

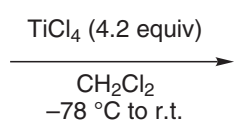

6

$\mathrm{R}^{1}=\mathrm{Ph}, t-\mathrm{Bu}$, OTMS, OPh

$\mathrm{R}^{2}, \mathrm{R}^{3}=\mathrm{Me}$

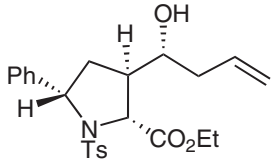

4 ( $87 \%$ ee)

$68-72 \%$ yield $\mathrm{dr}=99: 1$

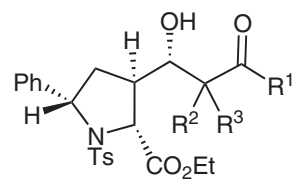

$61-83 \%$ yield $\mathrm{dr}=99: 1$
Significance: The report constitutes one of the few multicomponent reactions (MCR) that generate multiple stereocenters. The method created three contiguous stereocenters in a single operation. The rearrangement of furan adduct $\mathbf{5}$ to pyrrolidine $\mathbf{4}$ is an extension of a method developed previously by the same group (A. K. Ghosh, C.-X. Xu, S. S. Kulkarni, D. Wink Org. Lett. 2005, 7, 7-10). The reaction can be halted at the THF adduct $\mathbf{5}$ in the presence of MeCN as an additive. In all cases, the MCR yielded highly substituted proline derivatives $\mathbf{4}$ and $\mathbf{7}$ with excellent diastereoselectivity.

Review: D. J. Ramon, M. Yus Angew. Chem. Int. Ed. 2005, 44, 1602-1634.
Comment: The proposed mechanism for the conversion of $\mathbf{5}$ into $\mathbf{4}$ invokes formation of a benzylic carbocation promoted by $\mathrm{TiCl}_{4}$. It is noteworthy that an almost perfect retention of the stereochemistry was observed. An $\mathrm{S}_{\mathrm{N}} 2$ attack of the tosylamine on the activated benzylic ether was proposed to explain the observed stereochemical outcome. It should be noted that hydrides instead of allyl nucleophiles (3) were also effective $\left(\mathrm{Et}_{3} \mathrm{SiH}=\right.$ $69 \%, \mathrm{Bu}_{3} \mathrm{SnH}=53 \%$ ), but the selectivity was reduced (90:10 and 85:15, respectively). When enolsilanes or ketene acetals 6 were used as one component, an excess of Lewis acid was necessary to get full conversion into pyrrolidine derivatives $\mathbf{7}$.

SYNFACTS Contributors: Mark Lautens, Frédéric Ménard 